\title{
PEMBERDAYAAN SOSIAL MASYARAKAT \\ (Studi Deskriptif Tentang Perubahan Perilaku Masyarakat Kelurahan Fandoi \\ Dalam Pemberdayaan Tas Noken Sebagai Sumber Penghasilan)
}

\author{
Busyairi Ahmad \\ Program Studi Sosiologi, Fakultas Ilmu Sosial dan Ilmu Politik \\ Institut Ilmu Sosial dan Ilmu Politik YAPIS Biak \\ Email : Busyairi_ahmad@iyb.ac.id
}

\begin{abstract}
Abstrak
Pemberdayaan pada hakikatnya adalah upaya pemberian daya atau peningkatan keberdayaan. Penelitian ini bertujuan untuk mengetahui Perubahan Perilaku Masyarakat Kelurahan Fandoi Dalam Pemberdayaan Tas Noken Sebagai Sumber Penghasilan. Teknik pengumpulan data yang digunakan yaitu; observasi, wawancara, dan dokumentasi. Metode analisis yang digunakan adalah analisis kualitatif. Hasil penelitian menunjukkan bahwa terlihat tidak adanya keterlibatan pemerintah kelurahan Fandoi dalam sosialisasi ataupun pemberian bantuan terhadap pemberdayaan warga dikelurahan Fandoi, Sehingga warga masyarakat kelurahan fandoi memutuskan untuk membangun usaha sendiri. Dimana mereka membuat usaha tas noken tanpa bantuan sedikitpun dari pemerintah kelurahan Fandoi.
\end{abstract}

Kata Kunci: Pemberdayaan, Perilaku dan Masyarakat.

\section{PENDAHULUAN}

Pembangunan desa memegang peranan yang penting karena merupakan bagian yang tidak terpisahkan dan hakikatnya terhadap pembangunan daerah dan nasional.Hal tersebut terlihat dari melalui program pembangunan dan pemberdayaan sosial masyarakat yang direncanakan pemerintah untuk pembangunan desa.Hampir semua instansi, terutama pemerintah daerah mengakomodir pembangunan dan pemberdayaan sosial masyarakat desa dalam program kerjanya.Tentunya berdasarkan pemahaman bahwa desa sebagai kesatuan geografis terdepan yang merupakan tempat sebagian besar penduduk bermukim. Dalam struktur pemerintahan, desa menempati posisi terbawah, akan tetapi justru terdepan dan langsung berada di tengah masyarakat. Karenanya dapat di pastikan apapun bentuk setiap program pembangunan dan pemberdayaan sosial masyarakat dari pemerintah akan selalu bermuara ke desa.Mekipun demikian, pembangunan dan pemberdayaan sosial masyarakat desa masih memiliki berbagai permasalahan, seperti adanya desa terpencil atau terisolir, masih minimnya prasarana sosial ekonomi serta penyebaran jumlah tenaga masyarakat produktif yang tidak seimbang.Termasuk tingkat produktifitas, tingkat pendapatan masyarakat, dan tingkat pendidikan yang relatif masih rendah semuanya itu pada akhirnya berkontribusi pada kemiskinan penduduk.

Faktor tersebut menyebabkan pemerintah semakin intensif menggulirkan program pemberdayaan sosial masyarakat dalam pelaksanaan pembangunan desa. Namun demikian program pembangunan pemberdayaan sosial masyarakat dalam pelaksanaan pembangunan desa justru tidak dapat berjalan optimal, karena di rencanakan 
jauh dari desa. Masyarakat masih dianggap objek atau sasaran yang akan dibangun. Hubungan yang terbangun adalah pemerintah sebagai subjek atau pelaku pembangunan dan pemberdayaan dan masyarakat desa sebagai objek atau sasaran pembangunan.Partipasi yang ada masih sebatas pemanfaatan hasil. Tingkat partisipasi dalam pembangunan dan pemberdayaan masih sebatas peran serta secara fisik tanpa berperan secara luas sejak dari perencanaan sampai evaluasi.

Hal ini yang membuat pemerintah berupaya untuk membangun desa melalui pemberdayaan sosial masyarakat sehingga tercapainya kesejahteraan masyarakat. Pemberdayaan pada hakikatnya adalah upaya pemberian daya atau peningkatan keberdayaan.Pemberdayaan masyarakat dapat diartikan sebagai upaya untuk memandirikan masyarakat agar mampu berpartisipasi aktif dalam segala aspek pembangunan.Kemandirian bukan berarti mampu hidup sendiri tapi mandiri dalam pengambilan keputusan, yaitu memiliki kemampuan untuk memilih dan keberanian menolak segala bentuk bantuan dan atau kerjasama yang tidak menguntungkan. Pemberdayaan masyarakat adalah proses pembangunan sumber daya manusia atau masyarakat itu sendiri dalam bentuk penggalian kemampuan pribadi, kreatifitas, kompetensi dan daya pikir serta tindakan yang lebih baik dari waktu sebelumnya. Pemberdayaan masyarakat sangat penting dan merupakan hal yang wajib untuk dilakukan mengingat pertumbuhan ekonomi dan teknologi yang demikian pesatnya belakangan ini akan mempengaruhi kemampuan tiap individu dalam memenuhi kebutuhan hidupnya.

Pemberdayaan sosial masyarakat saat ini banyak dikaitkan dengan masyarakat desa. Hal ini dikarnakan rata-rata pola pikir masyarakat desa cenderung lebih terbelakang ketimbang masyarakat kota. Arti dari pemberdayaan masyarakat desa adalah proses membangun pola pikir dan kompetensi masyarakat desa agar bisa menyamai masyarakat kota atau bahkan bisa melebihi mereka. Pemberdayaan masyarakat di kelurahan Fandoi diharapkan dalam proses pembangunannya, dimana masyarakatnya mampu berinisiatif untuk memulai proses kegiatan sosial untuk memperbaiki situasi dan kondisi masyarakatnya sendiri, Khususnya untuk menambah penghasilan kehidupan mereka sehari-hari. Dimana peran masyarakat Fandoi hanya bisa terjadi apabila masyarakat itu sendiri ikut pula berpartisipasi.

Kelurahan Fandoi merupakan suatu wilayah yang didiami oleh orang-orang yang mempunyai beragam persoalan yang dihadapi, khususnya persoalan ekonomi. Dimana masalah-masalah yang dihadapi khususnya masalah biaya kehidupan seharihari masyarakat di kelurahan fandoi, perlu adanya pemberdayaan sosial masyarakatnya yang disertai perubahan perilaku dalam setiap aggota masyarakatnya melalui suatu usaha yang dapat menghasilkan dan mampu memenuhi biaya kehidupan mereka seharihari. Salah satu contohnya dengan mengelolah serabut kayu ataupun berbagai jenis benang wol menjadi kerajinan yang bernilai ekonomis seperti Tas Noken. Sehingga berdampak bagi kesejahtraan dan kehidupan masyarakat di kelurahan Fandoi.

Demi kesejahtraan dan kelangsungan hidup masyarakat kelurahan Fandoi yang lebih baik, dimana kesenjangan hidup dapat menimbulkan rawan konflik baik perorangan maupun masyarakat yang ada di kelurahan Fandoi karena disebabkan kesetaraan hidup yang tidak seimbang dan 
mengakibatkan timbulnya satu masalah secara horizontal.Untuk mengantisipasi halhal yang tidak diinginkan maka perlu adanya perubahan hidup yang berdampak positif bagi setiap masyarakat, terutama masyarakat di kelurahan fandoi yang perlu mengalami perubahan khusunya dalam keuangan masyarakatnya.

Pemberdayaan menurut arti secara bahasa adalah proses, cara, perbuatan membuat berdaya, yaitu kemampuan untuk melakukan sesuatu atau kemampuan bertindak yang berupa akal, ikhtiar atau upaya (Depdiknas, 2003). Masyarakat adalah kesatuan hidup manusia yang berinteraksi menurut suatu sistem adat istiadat tertentu yang bersifat kontinyu, dan yang terikat oleh suatu rasa identitas bersama (Koentjaraningrat, 2009). Dalam beberapa kajian mengenai pembangunan komunitas, pemberdayaan masyarakat sering dimaknai sebagai upaya untuk memberikan kekuasaan agar suara mereka didengar guna memberikan kontribusi kepada perencanaan dan keputusan yang mempengaruhi komunitasnya (Foy, 1994). Pemberdayaan adalah proses transisi dari keadaan ketidakberdayaan ke keadaan kontrol relatif atas kehidupan seseorang, takdir, dan lingkungan (Sadan,1997). Menurut Mubarak (2010) pemberdayaan masyarakat dapat diartikan sebagai upaya untuk memulihkan atau meningkatkan kemampuan suatu komunitas untuk mampu berbuat sesuai dengan harkat dan martabat mereka dalam melaksanakan hak-hak dan tanggung jawabnya selaku anggota masyarakat.

Pada Pemberdayaan pendekatan proses lebih memungkinkan pelaksanaan pembangunan yang memanusiakan manusia. Dalam pandangan ini pelibatan masyarakat dalam pembangunan lebih mengarah kepada bentuk partisipasi, bukan dalam bentuk mobilisasi. Partisipasi masyarakat dalam perumusan program membuat masyarakat tidak semata-mata berkedudukan sebagai konsumen program, tetapi juga sebagai produsen karena telah ikut serta terlibat dalam proses pembuatan dan perumusannya, sehingga masyarakat merasa ikut memiliki program tersebut dan mempunyai tanggung jawab bagi keberhasilannya serta memiliki motivasi yang lebih bagi partisipasi pada tahap-tahap berikutnya (Soetomo, 2006).

Menurut Jimu (2008) menunjukkan bahwa pengembangan masyarakat tidak khususnya masalah ekonomi, teknis atau infrastruktur. Ini adalah masalah pencocokan dukungan eksternal yang ditawarkan oleh agen pembangunan pedesaan dengan karakteristik internal sistem pedesaan itu sendiri. Oleh karena itu, agen pembangunan pedesaan harus belajar untuk 'menempatkan terakhir terlebih dahulu' (Chambers, 1983 dalam Jimu, 2008). Konsep pemberdayaan menekankan bahwa orang memperoleh ketrampilan, pengetahuan, dan kekuasaan yang cukup untuk mempengaruhi kehidupannya dan kehidupan orang lain yang menjadi perhatiannya (Pearson et al, 1994 dalam Sukmaniar, 2007). Pemahaman mengenai konsep pemberdayaan tidak bisa dilepaskan dari pemahaman mengenai siklus pemberdayaan itu sendiri, karena pada hakikatnya pemberdayaan adalah sebuah usaha berkesinambungan untuk menempatkan masyarakat menjadi lebih proaktif dalam menentukan arah kemajuan dalam komunitasnya sendiri.

Menurut Wilson (1996) terdapat 7 tahapan dalam siklus pemberdayaan masyarakat.Tahap pertama yaitu keinginan dari masyarakat sendiri untuk berubah 
menjadi lebih baik. Pada tahap kedua, masyarakat diharapkan mampu melepaskan halangan-halangan atau factorfaktor yang bersifat resistensi terhadap kemajuan dalam dirinya dan komunitasnya. Pada tahap ketiga, masyarakat diharapkan sudah menerima kebebasan tambahan dan merasa memiliki tanggung jawab dalam mengembangkan dirinya dan komunitasnya. Tahap keempat yaitu upaya untuk mengembangkan peran dan batas tanggung jawab yang lebih luas, hal ini juga terkait dengan minat dan motivasi untuk melakukan pekerjaan dengan lebih baik. Pada tahap kelima ini hasil-hasil nyata dari pemberdayaan mulai kelihatan, dimana peningkatan rasa memiliki yang lebih besar menghasilkan keluaran kinerja yang lebih baik. Pada tahap keenam telah terjadi perubahan perilaku dan kesan terhadap dirinya, dimana keberhasilan dalam peningkatan kinerja mampu meningkatkan perasaan psikologis di atas posisi sebelumnya. Pada tahap ketujuh masyarakat yang telah berhasil dalam memberdayakan dirinya, merasa tertantang untuk upaya yang lebih besar guna mendapatkan hasil yang lebih baik.

\section{METODE PENELITIAN}

\section{Lokasi Penelitian}

Lokasi penelitian ini, yakni di Kelurahan Fandoi Kabupaten Biak Numfor.Penetapan tempat ini didasarkan pada lokasi yang dipilih oleh peneliti.

\section{Jenis Penelitian}

Jenis penelitian adalah deskriptif kualitatif, yaitu salah satu jenis penelitian yang termasuk dalam jenis penelitian kualitatif. Dimana tujuan penelitian ini adalah untuk mengungkapkan fakta, keadaan, fenomena, variabel dan keadaan yang terjadi saat penelitian berlangsung dan menyuguhkan apa yang sebenarnya terjadi.

\section{Sumber Data}

Data Primer, yaitu data yang secara langsung diperoleh dari sumbernya, melalui wawancara, observasi dan pendokumentasian. selain itu, data yang didapatkan dari studi dokumen dalam penelitian ini merupakan data yang juga dikategorikan sebagai data primer. Data sekunder, yaitu data yang diperoleh melalui studi pustaka, yakni data yang diperoleh melalui buku, internet dan sebagainya yang berhubungan dengan tujuan penelitian. Sumber Data Sumber data penelitian yaitu berasal dari beberapa responden dari masyarakaat kelurahan fandoi itu sendiri.Dimana respondennya sebanyak 10 responden.

\section{Teknik Pengumpulan Data}

Data-data yang dibutuhkan dalam penelitian ini diperoleh melalui cara-cara yaitu: Wawancara, observasi Lapangan, Angket (kuisioner), Studi Kepustakaan.

\section{Teknik Analisis Data}

Analisis data dalam penelitian ini menggunakan model intraktif Miles dan Huberman, yakni model yang terdiri dari tiga proses yang berlangsung secara intraktif. Pertama, reduksi data yang merupakan proses memilih, memfokuskan, menyederhanakan, dan mengabstrasikan data dari berbgai sumber, misalnya dari dokumen, cacatatan lapangan dan sebagainya. Yang diajukan dengan proses mempertegas, menyederhanakan data, membuang data yang tidak perlu, menentukan fokus dan pengaturan data untuk penarikan kesimpulan. Yang kedua, penyajian data yang merupakan proses 
menyusun / merakit data dan menyajikannya dengan baik supaya lebih mudah dipahami.

\section{HASIL DAN PEMBAHASAN}

\section{A. Kegiatan Pembuatan Tas Noken Dalam Upaya Pemberdayaan Pada Warga Kelurahan Fandoi}

Pada pemberdayaan pendekatan proses lebih memungkinkan pelaksanaan pembangunan yang memanusiakan manusia dalam pandangan ini melibatan masyarakat dalam pembangunan lebih mengarah kepada bentuk partisipasi, bukan dalam bentuk mobilisasi. Partisipasi masyarakat dalam perumusan program membuat masyarakat tidak semata-mata berkedudukan sebagai konsumen program, tetapi juga sebagai produsen karena telah ikut serta terlibat dalam proses pembuatan dan perumusannya, sehingga masyarakat merasa ikut memiliki program tersebut dan mempunyai tanggung jawab bagi keberhasilannya serta memiliki motivasi yang lebih bagi partisipasi pada tahap-tahap berikutnya (Soetomo,2006). Masyarakat adalah kesatuan hidup manusia yang berinteraksi menurut suatu sistem adat istiadat tertentu yang bersifat kontinyu, dan yang terikat oleh suatu rasa identitas bersama (Koentjaraningrat,2009).

Menurut Mubarak

pemberdayaan masyarakat dapat diartikan sebagai upaya untuk memulihkan atau meningkatkan kemampuan suatu komunitas untuk mampu berbuat sesuai dengan harkat dan martabat mereka dalam melaksanakan hak-hak dan tanggung jawabnya selaku anggota masyarakatnya. Dalam pembahasan ini dimana akan diuraikan hasil wawancara yang peneliti sajikan dalam bentuk hasil wawancara tertulis berdasarkan fokus penelitian yaitu Kegiatan Pembuatan Tas Noken Dalam Upaya Pemberdayaan Pada Warga Kelurahan Fandoi. Hasil wawancara tertulis merupakan salinan atas wawancara yang dilakukan dilapangan peneliti kepada narasumber, pelaksanaan wawancara dilakukan dalam kurun waktu dua minggu dengan melibatkan informan sebagaimana yang tertera dalam perencenaan penelitian ini. Hasil wawancara tertulis merupakan salinan atas wawancara yang dilakukan dilapangan penelitian kepada informan. Untuk mengetahui bagaimana Kegiatan Pembuatan Tas Noken Dalam Upaya Pemberdayaan Pada Warga Kelurahan Fandoi. Berikut ini, penulis dapat menyajikan hasil sejumlah wawancara lisan kepada beberapa responden.Kesemuannya ditujukan kepada beberapa warga masyarakat setempat pada Kelurahan Fandoi. Untuk mengetahui Kegiatan Pembuatan Tas Noken Dalam Upaya Pemberdayaan Pada Warga Kelurahan Fandoi, maka penulis mengajukan beberapa pertanyaan kepada narasumber yaitu pertanyaan pertama, Apakah dalam pembuatan tas noken pemerintah kelurahan Fandoi mengadakan sosialisasi atau memberikan bantuan untuk warga kelurahan Fandoi. Menurut Narasumber Herinda Watopa mengatakan :

“..........Tidak. Selama saya tinggal dan menjadi warga kelurahan Fandoi tdak pernah ada sosialisasi ataupun bantuan dari pemerintah kelurahan Fandoi terkait pemberdayaan pembuatan tas noken itu sendiri. Dan kami belajar secara otodida dan turun temurun dalam pembuatan tas noken tersebut"

Menurut narasumber Meriona mengatakan:

"Tidak. Selama saya tinggal dan menjadi warga kelurahan fandoi tdak pernah ada sosialisasi ataupun 
bantuan dari pemerintah kelurahan fandoi terkait pemberdayaan pembuatan tas noken itu sendiri”.

Dari hasil wawancara tersebut terlihat bahwa tidak adanya keterlibatan pemerintah kelurahan fandoi dalam sosialisasi ataupunpemberian bantuan terhadap pemberdayaan warga dikelurahan fandoi. Berdasarkan observasi yang peneliti lakukan dikelurahan fandoi dan dengan keterbatasan waktu peneliti bahwa informasi pada sesi wawancara yang disampaikan oleh narasumber, yang mana tidak adanya sosialisasi ataupun bantuan dari upaya pemberdayaan pada warga kelurahan fandoi dari pemerintah kelurahan fandoi.

Untuk mengetahui Kegiatan

Pembuatan Tas Noken Dalam Upaya Pemberdayaan Pada Warga Kelurahan Fandoi, maka penulis mengajukan beberapa pertanyaan kepada narasumber yaitu pertanyaan kedua,Dalam pembuatan tas noken, dimana dalam pembuatannya dikerjakan satu orang atau perkelompok. Menurut Narasumber Herinda Watopa mengatakan:

"Kalau saya membuatnya sendiri saja.Tapi tergantung juga maksudnya jika ada pesanan biasanya baru bikinnya perkelompok karna yang biasa memesan memberikan batas waktu. Jadi agar pelanggang puas dan tepat waktu maka dalam situasi ini pembuatan tas noken dikerjakan secara perkelompok".

Menurut Narasumber Meriona Kayame mengatakan:

"Kalau saya biasa membuatnya sendiri saja. Karena terbatasi oleh bahan-bahan yang ada".
Berdasarkan observasi yang peneliti lakukan dikelurahan Fandoi dan dengan keterbatasan waktu peneliti bahwa informasi pada sesi wawancara yang disampaikan oleh narasumber, yang mana dalam pembuatan tas noken biasanya dilakukan sendiri, adapun perkelompok itupun jika adanya pesanan dan ada batas waktu yang diberikan oleh sang pemesan tas noken tersebut.

Dalam hasil wawancara pula terlihat bahwa dalam pembuatan tas noken, memerlukan waktu sesuai dengan ukuran tas noken itu sendiri. Kalau tas noken ukuran kecil terbuat dari benang wol waktu pembuatannya cukup satu hari saja. Kalau yang sedang butuh waktu dua hari. Kalau tas noken ukuran kecil yang terbuat dari kulit kayu memerlukan waktu dua hari. Sedangkan yang ukuran sedang memerlukan waktu tiga sampai empat hari. Dan tas noken ukuran besar yang biasa digunakan untuk mengangkat sayuran dan menggendong anak memerlukan waktu satu minggu atau lebih. Disamping itu, berdasarkan observasi yang peneliti lakukan dikelurahan fandoi dan dengan keterbatasan waktu peneliti bahwa informasi pada sesi wawancara yang disampaikan oleh narasumber, yang mana dalam pembuatan tas noken memerlukan waktu sesuai dengan ukuran tas noken itu sendiri. Kalau tas noken ukuran kecil terbuat dari benang wol waktu pembuatannya cukup satu hari saja. Kalau yang sedang butuh waktu dua hari. Kalau tas noken ukuran kecil yang terbuat dari kulit kayu memerlukan waktu dua hari. Sedangkan yang ukuran sedang memerlukan waktu tiga sampai empat hari. Dan tas noken ukuran besar yang biasa.

\section{B. Perubahan Perilaku Masyarakat Setelah Adanya Pemberdayaan}


Menurut (Selo Soemardjan dan Soeleman Soemardi) bahwa perubahanperubahan diluar bidang ekonomi tidak dapat dihindarkan oleh karena setiap perubahan dalam suatu lembaga kemasyarakatan akan mengakibatkan pula perubahan-perubahan di dalam lembagalembaga kemasyarakatan lainnya. Oleh karena antara lembaga-lembaga kemasyarakatan tersebut selalu ada proses saling mempengaruhi secara timbal balik. Setiap perkembangan zaman tentunya perubahan juga akan terus terjadi, perubahan memiliki efek positif dan negatif. Perubahan yang positif adalah perubahan yang terjadi kearah kemajuan suatu keadaan namunperubahan yang negative adalah perubahan kearah suatu yang merugikan.

Menurut (Imam Santoso, 2011) perubahan merupakan sifat dasar dari masyarakat. Ini mengubah metafor "kehidupan sosial" seperti kehidupan sosial itu sendiri. Kehidupan sosial meliputi perubahan yang telah henti. Gagasan paling umum dari perubahan mengindikasikan beberapa peralihan dalam hal entitas tertentu yang terjadi dalam waktu tertentu. Menurut (Nanang, Martono 2012) bahwa perubahan dapat mencakup aspek yang sempit maupun yang luas. Aspek yang sempit dapat meliputi aspek perilaku dan pola pikir individu. Aspek yang luas dapat berupa perubahan dalam tingkat struktur masyarakat yang nantinya dapat memengaruhi perkembangan masyarakat dimasa yang akan datang.

Hasil wawancara tertulis merupakan salinan atas wawancara yang dilakukan dilapangan penelitian kepada informan.Untuk mengetahui bagaimana Perubahan Perilaku Masyarakat Setelah Adanya Pemberdayaan Pada Warga Kelurahan Fandoi.Berikut ini, penulis dapat menyajikan hasil sejumlah wawancara lisan kepada beberapa responden.Kesemuannya ditujukan kepada beberapa warga masyarakat setempat pada Kelurahan Fandoi. Untuk mengetahui Perubahan Perilaku Masyarakat Setelah Adanya Pemberdayaan Pada Warga Kelurahan Fandoi., maka penulis mengajukan beberapa pertanyaan kepada narasumber yaitu yang pertama, Bagaimanakah perubahan perilaku masyarakat setelah adanya usaha pembuatan tas noken. Adapun jawaban dari para narasumber yaitu, menurut Narasumber Herinda Watopa mengatakan;

"Memberikan dampak yang baik, karena yang awalnya kita hanya mengandalkan penghasilan suami, sekarang kita sudah bisa membantu penghasilan suami dari hasil penjualan tas noken".

Menurut Narasumber Meriona Kayame mengatakan :

"Perubahannya sangat baik, karena setelah adanya pembuatan dan penjualan tas noken bisa membantu memenuhi kebutuhan sehari-hari walaupun tidak banyak".

Dari hasil wawancara tersebut terlihat bahwa perubahan perilaku masyarakat setelah adanya usaha pembuatan tas noken memberikan dampak yang positf, karena yang awalnya hanya mengandalkan penghasilan suami, sekarang sudah bisa membantu penghasilan suami dari hasil penjualan tas noken. Berdasarkan observasi yang peneliti lakukan dikelurahan Fandoi dan dengan keterbatasan waktu peneliti bahwa informasi pada sesi wawancara yang disampaikan oleh narasumber, yang mana perubahan perilaku masyarakat setelah adanya usaha pembuatan tas noken memberikan dampak yang positf, karena yang awalnya hanya mengandalkan 
penghasilan suami, sekarang sudah bisa membantu penghasilan suami dari hasil penjualan tas noken.

\section{KESIMPULAN}

Kesimpulan merupakan hasil yang dicapai dari analisis data dalam penelitian tentang Kegiatan Pembuatan Tas Noken Dalam Upaya Pemberdayaan Pada Warga Kelurahan Fandoi dan Perubahan Perilaku Masyarakatnya. Dari pembahasan terdahulu dan berdasarkan observasi yang peneliti lakukan dikelurahan Fandoi dapat ditarik kesimpulan bahwa dari hasil wawancara tersebut terlihat tidak adanya keterlibatan pemerintah kelurahan Fandoi dalam sosialisasi ataupun pemberian bantuan terhadap pemberdayaan warga dikelurahan Fandoi, Sehingga warga masyarakat kelurahan Fandoi memutuskan untuk membangun usaha sendiri. Dimana mereka membuat usaha tas noken tanpa bantuan sedikitpun dari pemerintah kelurahan fandoi.

\section{DAFTAR PUSTAKA}

Husaini Usman, dkk, (2003). Metodologi Penilitian Sosial. PT. Bumi Aksara.

Kuswata Agus Toha, (1984). Manajemen Pembangunan Desa. Garafindu Utama: Jakarta

Kartasasmita, Ginandjar, (1995). Pemberdayaan Masyarakat, Sebuah Tinjauan administrasi II. Buletin Alumni SESPA. Edisi keEmpat, Jakarta.

Nawawi, Hadari. (2003) Metode Penilitian Sosial. Universitas Gaja Mada Pers: Yogyakarta.
Siagian, (1996). Perencanaan Partisipatif Pembangunan Masyarakat Desa (P3MD) Buku I dan III, Departemen Dalam Negeri, Direktorat Jenderal Pembangunan Masyrakat Desa. 